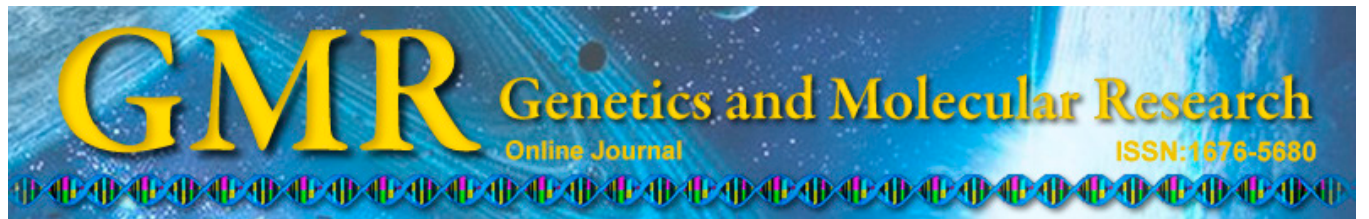

\title{
Effect of $R A G E$ polymorphisms on susceptibility to and severity of osteoarthritis in a Han Chinese population: a case-control study
}

H.Y. Yang ${ }^{1}$, S.Y. Chuang ${ }^{2}$, W.H. Fang ${ }^{3}$, G.S. Huang ${ }^{4}$, C.C. Wang ${ }^{2,5}$, Y.Y. Huang ${ }^{1}$, M.Y. $\mathrm{Chu}^{6}$, C. $\mathrm{Lin}^{5}$, W. Su${ }^{7}$, C.Y. Chen ${ }^{8}$, Y.T. Yang ${ }^{1}$ and S.L. Su${ }^{1}$

${ }^{1}$ School of Public Health, National Defense Medical Center, Taipei, Taiwan, China
${ }^{2}$ Department of Orthopedics,
Tri-Service General Hospital and National Defense Medical Center,
Taipei, Taiwan, China
${ }^{3}$ Department of Family and Community Medicine,
Tri-Service General Hospital, Taipei, Taiwan, China
${ }^{4}$ Department of Radiology, Tri-Service General Hospital, Taipei, Taiwan, China
${ }^{5}$ Graduate Institute of Life Sciences,
National Defense Medical Center, Taipei, Taiwan, China
${ }^{6}$ Department of Aviation Medicine and Physical Examination,
National Defense Medical Center Tri-Service General Hospital Songshan Branch,
Taipei, Taiwan, China
${ }^{7}$ Department of Nursing, Chang Gung University of Science and Technology,
Taoyuan, Taiwan, China
${ }^{8}$ Division of Radiology,
National Defense Medical Center Tri-Service General Hospital Songshan Branch,
Taipei, Taiwan, China
Corresponding author: S.L. Su
E-mail: a131419@gmail.com

Genet. Mol. Res. 14 (3): 11362-11370 (2015)

Received February 20, 2015

Accepted June 10, 2015

Published September 25, 2015

DOI http://dx.doi.org/10.4238/2015.September.25.3

ABSTRACT. Recent studies have revealed that the inflammatory process plays a role in the pathogenesis of osteoarthritis (OA). The S100 family and receptor for advanced glycation end products (RAGE) 
participate in regulating inflammation, even in the production of matrix metalloproteinases (MMPs). MMP-1 degrades cartilage, which may result in OA development. Moreover, polymorphisms in $R A G E$, $S 100 A 8$, and $M M P-1$ have a marked effect on ligand binding and transcription regulating. In this study, we investigated the potential genetic contribution of the RAGE, S100A8, and $M M P-1$ genes to OA. We performed a matched case-control association study and genotyped OA patients and healthy controls, who were analyzed by polymerase chain reaction-restriction fragment length polymorphism assays. A total of 207 patients were diagnosed with knee OA and underwent total knee replacement. The control group included 207 individuals who had standard X-rays of the knee joints to confirm $\mathrm{K} / \mathrm{L}<2$ and were matched by age and gender. Single-nucleotide polymorphisms in RAGE (-429T/C, -374T/A, and 557G/A), S100A8 (rs3795391A/G), and $M M P-1$ (-1607 1G/2G, $-755 \mathrm{G} / \mathrm{T}$, and $-519 \mathrm{~A} / \mathrm{G})$ were evaluated. $R A G E$ -374T/A, S100A8 rs3795391A/G, MMP-1 -1607 1G/2G, -755G/T, and $-519 \mathrm{~A} / \mathrm{G}$ showed no significant difference between OA patients and healthy controls. $R A G E-429 \mathrm{~T} / \mathrm{C}$ and $557 \mathrm{G} / \mathrm{A}$ showed a significant association between $\mathrm{OA}$ patients and healthy controls $(\mathrm{P}=0.016$ and 0.047 , respectively). In haplotype analyses, no $R A G E$ and $M M P-1$ haplotypes showed associations with OA. Our results suggest that the investigated polymorphism in the $R A G E$ gene play a role in OA in the Han Chinese population.

Key words: Matrix metalloprotease-1; Osteoarthritis; Polymorphism; Receptor for advanced glycation end products; S100A8

\section{INTRODUCTION}

Osteoarthritis (OA) is a degenerative joint disease that causes progressive loss of joint function and is a leading cause of disability and impaired quality of life among the elderly in developed countries. OA is regarded as a multifactorial disease associated with a variety of risk factors, including genetic predisposition, aging, obesity, inflammation, and excessive mechanical loading (Zhang and Jordan, 2010). The increasing role of genetics in the pathogenesis of OA has been highlighted by epidemiological studies of family history and clustering, adoption studies, twin studies, and exploration of rare genetic disorders related to OA (Valdes and Spector, 2009). Several genome-wide association studies (Kerkhof et al., 2010; Zeggini et al., 2012; Pang et al., 2013) and candidate gene studies (Bratus et al., 2013; Gonzalez, 2013; Reynard and Loughlin, 2013) have suggested that polymorphisms in certain genes affects the pathogenesis of OA.

$\mathrm{OA}$ is a complex disease involving both biomechanical and metabolic factors that alter the tissue homeostasis of articular cartilage and subchondral bone (Sofat, 2009). Recent studies have revealed that the inflammatory process is involved in the pathogenesis of OA (Yuan et al., 2003). The small calcium-binding S100 protein family has been implicated in various inflammatory conditions. One member of the S100 family, S100A8, is predominantly expressed in phagocytes and is strongly associated with pro-inflammatory functions (Soko- 
love and Lepus, 2013). In addition, S100A8 has been identified in human articular cartilage, and its expression is upregulated in diseased tissue (Roth et al., 2001; van den Berg, 2011). The receptor for advanced glycation end products (RAGE) is a pattern-recognition receptor that binds to endogenous S100/calgranulins, amyloid- $\beta$-peptide, and high mobility group protein B1 (or amphoterin) to influence gene expression via activated signal transduction pathways (Reddy et al., 2006). RAGE participates in the regulation of inflammation (Hofmann et al., 1999). The interaction between S100A8 and RAGE increases matrix metalloproteinase (MMP) production and upregulates MMPs involved in mediating extracellular matrix destruction(Grogan and D'Lima, 2010). MMP-1 plays an important role in the degeneration of type II collagen, a primary extracellular matrix component. In OA cartilage, MMP-1 synthesis is increased (Martel-Pelletier and Pelletier, 1996).

Several reports have recently identified polymorphisms in the $S 100 A 8, R A G E$ and $M M P-1$ genes that may influence ligand binding or transcription regulation (Wicki et al., 1996; Ye, 2000; Hofmann et al., 2002).

$M M P-1$ polymorphism has been implicated in OA in a Turkish population, and RAGE polymorphism has been implicated in rheumatoid arthritis (RA) in Caucasians (Carroll et al., 2007; Barlas et al., 2009). However, no studies have analyzed the association between $R A G E$, S100A8, and MMP-1 single-nucleotide polymorphisms (SNPs) and OA in the Han Chinese population. We hypothesized that genetic polymorphisms in the RAGE, S100A8, and MMP1 genes lead to altered biological activities of functional proteins. The purpose of this study was to determine whether $R A G E, S 100 A 8$, and $M M P-1$ gene polymorphisms are markers of susceptibility to OA or its severity in a Han Chinese population.

\section{MATERIAL AND METHODS}

\section{Study population}

This study was a 1:1 matched case-control study. Cases were matched to controls by gender and age (within 5 years). OA cases who had undergone total knee joint replacement $(\mathrm{N}=207 ; 154$ females and 53 males; age $=70.08 \pm 7.41$ years $)$ for primary severe OA fulfilled the criteria of sufficiently severe signs and symptoms of $\mathrm{OA}$ to require joint replacement surgery. Other etiologies of knee joint OA, including inflammatory arthritis (i.e., rheumatoid, polyarthritic, or autoimmune disease), post-traumatic or post-septic arthritis, skeletal dysplasia, or developmental dysplasia, were excluded. Healthy control subjects (age, $71.03 \pm 7.76$ years) showed no signs or symptoms of joint disease (pain, swelling, tenderness, or restriction of movement), and standard X-rays of the knee joints confirmed the absence of OA. The ethics review committee of the Tri-Service General Hospital approved the study, and written informed consent was obtained from all participants (TSGH-100-05-023).

\section{Selection and genotyping of polymorphisms}

SNP genotype information was downloaded from the HapMap database (http://hapmap.ncbi.nlm.nih.gov/) and the National Center for Biotechnology Information dbSNP database (http://www.ncbi.nlm.nih.gov/snp). Tag SNPs were selected for RAGE, S100A8, and $M M P-1$ genes using the criteria of minor allele frequency (MAF) $>5 \%$ and those in regulatory regions or reported by other investigators. Genomic DNA was extracted from peripheral blood 
samples using a QIAamp DNA Blood Mini Kit (Qiagen, Hilden, Germany). The RAGE [-429 T/C (rs1800625), -374 T/A (rs1800624), and 557 G/A (rs2070600)], S100A8 (rs3795391), and MMP1 [-1607 2G/1G (rs1799750), -755 G/T (rs498186), and -519 A/G (rs1144393)] polymorphisms were screened using a thermocycler polymerase chain reaction (PCR) system 9700 (GeneAmp, Applied Biosystems, Foster City, CA, USA), followed by a restriction fragment length polymorphism assay. The PCR samples contained $10 \mathrm{X}$ buffer, $1.5 \mathrm{mM} \mathrm{MgCl}$, $0.2 \mathrm{mM}$ of each dNTP, and $1 \mathrm{U}$ Taq DNA polymerase. PCR-grade water was added to a final volume of $50 \mu \mathrm{L}$. PCR products were digested with the respective restriction endonucleases (New England Biolabs, Inc., Ipswich, MA, USA), and the resulting fragments were separated on a $2.5 \%$ agarose gel containing $0.5 \mu \mathrm{g} / \mathrm{mL}$ ethidium bromide by electrophoresis at $100 \mathrm{~V}$ and visualized under UV light. Primer design was based on published sequences (Jurajda et al., 2002; Jin et al., 2005; Li et al., 2007; Checa et al., 2008; Kalousova et al., 2009; Daborg et al., 2010). The details of the primers, PCR conditions, restriction enzymes, and genotype configurations are shown in Table 1. Genotyping was performed by blinding of case and control status. To validate the genotyping results, at least $10 \%$ of samples were randomly selected for repeated genotyping.

\begin{tabular}{|c|c|c|c|}
\hline Gene & Polymorphism & Primer sequence $\left(5^{\prime}-3^{\prime}\right)$ & $\begin{array}{l}\text { Annealing temperature; product size; } \\
\text { Restriction enzyme; } \\
\text { Products after digestion }\end{array}$ \\
\hline$R A G E$ & $-429 \mathrm{~T} / \mathrm{C}$ & $\begin{array}{l}\text { F: GGGGCAGTTCTCTCCTCACT } \\
\text { R: GGTTCAGGCCAGACTGTTGT }\end{array}$ & $59.5^{\circ} \mathrm{C} ; 250 \mathrm{bp} ; A l u \mathrm{I} ; 162+88 \mathrm{bp}$ \\
\hline$R A G E$ & $-374 \mathrm{~T} / \mathrm{A}$ & $\begin{array}{l}\text { F: GGGGCAGTTCTCTCCTCACT } \\
\text { R: GGTTCAGGCCAGACTGTTGT }\end{array}$ & $59.5^{\circ} \mathrm{C} ; 250 \mathrm{bp} ; M f e \mathrm{I} ; 215+35 \mathrm{bp}$ \\
\hline$R A G E$ & $557 \mathrm{G} / \mathrm{A}$ & $\begin{array}{l}\text { F: GTAAGCGGGGCTCCTGTTGCA } \\
\text { R: GGCCAAGGCTGGGGTTGAAGG }\end{array}$ & $62^{\circ} \mathrm{C} ; 397 \mathrm{bp} ;$ AluI; $248+181+149+67 \mathrm{bp}$ \\
\hline$S 100 A 8$ & rs3795391 A/G & $\begin{array}{l}\text { F: GTGTGCACATGTCTCTGTGTG } \\
\text { R: CAACATGATGCCCACGGAACTTGC }\end{array}$ & $60^{\circ} \mathrm{C} ; 248 \mathrm{bp} ;$ TfiI $; 194+147+54+47 \mathrm{bp}$ \\
\hline$M M P-1$ & $-16072 \mathrm{G} / 1 \mathrm{G}$ & $\begin{array}{l}\text { F: TGACTTTTAAAACTGACTTTTAAAA } \\
\text { CATAGTCTATGTTCA } \\
\text { R: TCTTGGATTGATTTGAGATAAGTCATAGC }\end{array}$ & $58^{\circ} \mathrm{C} ; 269 \mathrm{bp} ;$ AluI $; 241+28$ bp \\
\hline$M M P-1$ & $-755 \mathrm{G} / \mathrm{T}$ & $\begin{array}{l}\text { F: GATCCTCCCACCTCAGCCTCTTCCG } \\
\text { R: CATGGTGAGACCCCATCTCT }\end{array}$ & $67^{\circ} \mathrm{C} ; 120 \mathrm{bp} ; M s p \mathrm{I} ; 97+23 \mathrm{bp}$ \\
\hline$M M P-1$ & $-519 \mathrm{~A} / \mathrm{G}$ & $\begin{array}{l}\text { F: CATGGTGCTATCGCAATAGGGT } \\
\text { R: TGCTACAGGTTTCTCCACACAC }\end{array}$ & $54^{\circ} \mathrm{C} ; 200 \mathrm{bp} ; K p n \mathrm{I} ; 176+24$ bp \\
\hline
\end{tabular}

\section{Statistical analysis}

The demographics were evaluated using the Student $t$-test for continuous variables and reported as means \pm standard deviation. For each SNP, deviation from Hardy-Weinberg equilibrium in the cases and controls was assessed using the standard $\chi^{2}$ test. The allele and genotype frequencies of case and control groups were compared using $\chi^{2}$ statistics or the Fisher exact test when the expected count was less than 5 in $>33 \%$ of the input cells of the contingency table. Conditional logistic regression was used to estimate crude and adjusted (age, gender, and body mass index) odd ratios (ORs) and 95\% confidence intervals (CIs) as a measure of association with the risk of OA. Linkage disequilibrium and haplotype analyses were performed using the Haploview software (http://www.broad.mit.edu/mpg/haploview/). Data were analyzed with the SPSS statistical software 18.0 (SPSS Inc., Chicago, IL, USA), and the results were considered to be statistically significant when the 2-tailed $\mathrm{P}$ value was $<0.05$. 


\section{RESULTS}

\section{Basic characteristics of the study population}

Table 2 shows demographic and clinical characteristics of all subjects in the study. A significant difference in body mass index was observed between OA individuals and controls $(\mathrm{P}<0.01)$. There was no significant difference in age or gender between the 2 groups.

Table 2. Characteristics of the study subjects.
\begin{tabular}{lccc} 
& & \\
\hline & Cases & Controls & P value \\
\hline Number & 207 & 207 & \\
Age (years) & $70.08 \pm 7.41$ & $71.03 \pm 7.76$ & 0.204 \\
Gender $($ male/female $)$ & $53 / 154$ & $53 / 154$ & - \\
BMI $\left(\mathrm{kg} / \mathrm{m}^{2}\right)$ & $27.40 \pm 3.58$ & $24.12 \pm 3.18$ & $<0.001$ \\
\hline
\end{tabular}

\section{Distributions of $R A G E, S 100 A 8$, and $M M P-1$ gene polymorphisms and their association with $\mathrm{OA}$}

The RAGE (-429 T/C, -374 T/A, and $557 \mathrm{G} / \mathrm{A})$, S100A8 (rs3795391 A/G), and $M M P-1$ gene $(-16072 \mathrm{G} / 1 \mathrm{G},-755 \mathrm{G} / \mathrm{T}$, and $-519 \mathrm{~A} / \mathrm{G})$ genotype distributions were all in Hardy-Weinberg equilibrium in cases and controls $(\mathrm{P}>0.05)$, indicating that the study subjects were representative of the study field. The genotypic and allelic distributions of the 3 SNPs in RAGE and their associations with OA risk are shown in Table 3. The genotypic and allelic distributions of $557 \mathrm{G} / \mathrm{A}$ in $R A G E$ were significantly different between OA cases and healthy controls $(\mathrm{P}<0.05)$. In $R A G E 557 \mathrm{G} / \mathrm{A}$, when the $\mathrm{GG}$ genotype was used as the reference group, the AA genotype was associated with a higher risk of $\mathrm{OA}$ (adjusted $\mathrm{OR}=2.78$, $95 \% \mathrm{CI}=1.02-7.63, \mathrm{P}=0.047)$. The association between the $R A G E-429 \mathrm{~T} / \mathrm{C}$ polymorphism and risk of OA was significant, with the heterozygous carrier being at lower risk (adjusted $\mathrm{OR}=0.42,95 \% \mathrm{CI}=0.21-0.85, \mathrm{P}=0.016)$. The $-374 \mathrm{~T} / \mathrm{A} \mathrm{SNP}$ in $R A G E$ showed no significant genotypic and allelic association between the OA cases and healthy controls $(\mathrm{P}>0.05)$. There was no significant difference in the genotype or allele frequencies of the $S 100 A 8$ gene (rs3795391 A/G) and $M M P-1$ gene $(-16072 \mathrm{G} / 1 \mathrm{G},-755 \mathrm{G} / \mathrm{T}$, and $-519 \mathrm{~A} / \mathrm{G})$ polymorphisms among any of the patient and control groups. SNPs in the dominant and recessive modes showed no significance (data not shown).

\section{Haplotype analysis of $R A G E$ and $M M P-1$}

Haplotype analysis of the $R A G E$ and $M M P-1$ polymorphisms in OA patients and control subjects is shown in Table 4. Strong linkage disequilibrium was found among $R A G E-429$ $\mathrm{T} / \mathrm{C},-374 \mathrm{~T} / \mathrm{A}$, and $557 \mathrm{G} / \mathrm{A}\left(\mathrm{r}^{2}>0.70\right.$, data not shown). In the $M M P-1$ gene, $-755 \mathrm{G} / \mathrm{T}$ and $-519 \mathrm{~A} / \mathrm{G}\left(\mathrm{r}^{2}=1.00\right)$ also showed strong linkage disequilibrium (data not shown). Only 4 of the 8 possible haplotypes of $R A G E$ were observed in both OA patients and control subjects, but no haplotypes showed an association with OA. The haplotypes of the $M M P-1$ gene (-1607, $2 \mathrm{G} / 1 \mathrm{G}$, and $-755 \mathrm{G} / \mathrm{T}$ ) showed no significant difference. 


\begin{tabular}{|c|c|c|c|c|c|c|}
\hline SNP & Cases & Controls & Crude OR $(95 \% \mathrm{CI})$ & $P$ & Adjusted OR $(95 \% \mathrm{CI})^{*}$ & $\mathrm{P}$ \\
\hline \multicolumn{7}{|c|}{$R A G E-429 \mathrm{~T} / \mathrm{C}$} \\
\hline $\mathrm{T} / \mathrm{T}$ & 186 & 174 & 1 & & 1 & \\
\hline $\mathrm{C} / \mathrm{T}$ & 18 & 31 & $0.54(0.29-1.01)$ & 0.052 & $0.42(0.21-0.85)$ & 0.016 \\
\hline $\mathrm{C} / \mathrm{C}$ & 3 & 2 & $1.40(0.23-8.50)$ & 0.712 & $1.25(0.19-8.10)$ & 0.813 \\
\hline C-allele & 0.94 & 0.92 & $0.67(0.39-1.14)$ & 0.137 & $0.56(0.31-1.02)$ & 0.056 \\
\hline \multicolumn{7}{|c|}{$R A G E-374 \mathrm{~T} / \mathrm{A}$} \\
\hline $\mathrm{T} / \mathrm{T}$ & 143 & 148 & 1 & & 1 & \\
\hline $\mathrm{A} / \mathrm{T}$ & 56 & 52 & $1.12(0.72-1.73)$ & 0.630 & $1.05(0.64-1.72)$ & 0.841 \\
\hline $\mathrm{A} / \mathrm{A}$ & 8 & 7 & $1.18(0.42-3.35)$ & 0.752 & $1.28(0.42-3.94)$ & 0.662 \\
\hline A-allele & 0.83 & 0.84 & $1.11(0.77-1.60)$ & 0.576 & $1.09(0.73-1.63)$ & 0.672 \\
\hline \multicolumn{7}{|c|}{$R A G E 557 \mathrm{G} / \mathrm{A}$} \\
\hline $\mathrm{G} / \mathrm{G}$ & 109 & 128 & 1 & & 1 & \\
\hline $\mathrm{A} / \mathrm{G}$ & 84 & 71 & $1.39(0.93-2.09)$ & 0.113 & $1.38(0.87-2.18)$ & 0.169 \\
\hline $\mathrm{A} / \mathrm{A}$ & 14 & 8 & $2.06(0.83-5.08)$ & 0.119 & $2.78(1.02-7.63)$ & 0.047 \\
\hline A-allele & 0.73 & 0.79 & $1.39(1.01-1.92)$ & 0.042 & $1.49(1.04-2.13)$ & 0.031 \\
\hline \multicolumn{7}{|c|}{$S 100 A 8 \mathrm{rs} 3795391 \mathrm{~A} / \mathrm{G}$} \\
\hline $\mathrm{A} / \mathrm{A}$ & 171 & 163 & 1 & & 1 & \\
\hline $\mathrm{A} / \mathrm{G}$ & 36 & 43 & $0.80(0.49-1.31)$ & 0.369 & $0.89(0.51-1.54)$ & 0.674 \\
\hline $\mathrm{G} / \mathrm{G}$ & 0 & 1 & - & - & - & - \\
\hline G-allele & 0.91 & 0.89 & $0.78(0.49-1.24)$ & 0.292 & $0.87(0.52-1.45)$ & 0.597 \\
\hline \multicolumn{7}{|c|}{$M M P 1-16072 \mathrm{G} / 1 \mathrm{G}$} \\
\hline $2 \mathrm{G} / 2 \mathrm{G}$ & 92 & 98 & 1 & & 1 & \\
\hline $2 \mathrm{G} / 1 \mathrm{G}$ & 88 & 89 & $0.73(0.38-1.40)$ & 0.347 & $0.91(0.44-1.91)$ & 0.811 \\
\hline $1 \mathrm{G} / 1 \mathrm{G}$ & 27 & 20 & $0.70(0.37-1.33)$ & 0.269 & $0.82(0.40-1.70)$ & 0.591 \\
\hline $1 \mathrm{G}$-allele & 0.34 & 0.31 & $0.87(0.65-1.16)$ & 0.336 & $0.90(0.65-1.25)$ & 0.531 \\
\hline \multicolumn{7}{|c|}{$M M P 1-755 \mathrm{~T} / \mathrm{G}$} \\
\hline $\mathrm{T} / \mathrm{T}$ & 58 & 60 & 1 & & 1 & \\
\hline $\mathrm{T} / \mathrm{G}$ & 116 & 104 & $1.45(0.86-2.46)$ & 0.163 & $1.11(0.62-2.00)$ & 0.719 \\
\hline $\mathrm{G} / \mathrm{G}$ & 33 & 43 & $1.26(0.71-2.25)$ & 0.435 & $0.93(0.49-1.78)$ & 0.827 \\
\hline G-allele & 0.44 & 0.46 & $1.08(0.82-1.42)$ & 0.576 & $0.95(0.70-1.30)$ & 0.754 \\
\hline \multicolumn{7}{|c|}{$M M P 1-519 \mathrm{~A} / \mathrm{G}$} \\
\hline $\mathrm{A} / \mathrm{A}$ & 179 & 173 & 1 & & 1 & \\
\hline $\mathrm{A} / \mathrm{G}$ & 27 & 33 & $0.79(0.46-1.37)$ & 0.403 & $0.91(0.50-1.66)$ & 0.756 \\
\hline $\mathrm{G} / \mathrm{G}$ & 1 & 1 & $0.97(0.06-15.6)$ & 0.981 & $0.85(0.05-13.9)$ & 0.910 \\
\hline G-allele & 0.93 & 0.92 & $0.82(0.49-1.36)$ & 0.436 & $0.91(0.52-1.59)$ & 0.747 \\
\hline
\end{tabular}

*Adjusted for age, gender, and BMI.

Table 4. Haplotype frequencies in RAGE and MMP-1 between osteoarthritis patients and control subjects.

\begin{tabular}{|c|c|c|c|c|c|c|}
\hline & & & \multicolumn{2}{|c|}{ Frequency } & \multirow[t]{2}{*}{ OR $(95 \% \mathrm{CI})$} & \multirow[t]{2}{*}{ P value } \\
\hline & & & Case & Control & & \\
\hline \multicolumn{3}{|c|}{ RAGE } & & & & \\
\hline$-429 \mathrm{~T} / \mathrm{C}$ & $-374 \mathrm{~T} / \mathrm{A}$ & $557 \mathrm{G} / \mathrm{A}$ & & & & \\
\hline $\mathrm{T}$ & $\mathrm{T}$ & $\mathrm{G}$ & 0.515 & 0.551 & $0.86(0.66-1.14)$ & 0.296 \\
\hline $\mathrm{T}$ & $\mathrm{T}$ & A & 0.253 & 0.205 & $1.32(0.95-1.82)$ & 0.098 \\
\hline $\mathrm{T}$ & A & G & 0.160 & 0.155 & $1.04(0.71-1.51)$ & 0.838 \\
\hline \multirow[t]{2}{*}{$\mathrm{C}$} & $\mathrm{T}$ & G & 0.054 & 0.084 & $0.64(0.36-1.09)$ & 0.096 \\
\hline & MMP-1 & & & & & \\
\hline$-16072 \mathrm{G} / 1 \mathrm{G}$ & $-755 \mathrm{G} / \mathrm{T}$ & $-519 \mathrm{~A} / \mathrm{G}$ & & & & \\
\hline $2 \mathrm{G}$ & $\mathrm{G}$ & A & 0.369 & 0.403 & $0.87(0.65-1.14)$ & 0.309 \\
\hline $2 \mathrm{G}$ & $\mathrm{T}$ & A & 0.276 & 0.271 & $1.02(0.76-1.40)$ & 0.861 \\
\hline $1 \mathrm{G}$ & $\mathrm{T}$ & A & 0.214 & 0.186 & $1.20(0.85-1.68)$ & 0.307 \\
\hline $1 \mathrm{G}$ & $\mathrm{T}$ & $\mathrm{G}$ & 0.058 & 0.070 & $0.82(0.47-1.43)$ & 0.477 \\
\hline $1 \mathrm{G}$ & G & A & 0.071 & 0.056 & $1.29(0.73-2.26)$ & 0.372 \\
\hline $2 \mathrm{G}$ & $\mathrm{T}$ & G & 0.012 & 0.015 & $0.83(0.25-2.75)$ & 0.764 \\
\hline
\end{tabular}




\section{DISCUSSION}

We investigated the association between $R A G E, S 100 A 8$, and $M M P-1$ gene polymorphisms and $\mathrm{OA}$ and identified significant associations for $R A G E-429 \mathrm{~T} / \mathrm{C}$ and $557 \mathrm{G} / \mathrm{A}$. No associations with gene polymorphisms at $R A G E-374 \mathrm{~T} / \mathrm{A}$ or $S 100 A 8 \mathrm{rs} 3795391 \mathrm{~A} / \mathrm{G}$ or with $M M P-1-1607$ 2G/1G, $-755 \mathrm{~T} / \mathrm{G}$, and $-519 \mathrm{~A} / \mathrm{G}$ were identified.

$R A G E$ has been shown to play a role in OA (Loeser et al., 2005). Animal model studies have described a possible role of $R A G E$ in the onset and severity of arthritis (Hofmann et al., 2002; Kokkola et al., 2003). Relatively few studies have investigated the association between $R A G E$ polymorphisms and arthritis. Hofmann et al. (2002) reported that the RAGE $557 \mathrm{G} / \mathrm{A}$ polymorphism was correlated with the susceptibility to RA. A study of 233 patients in a Han Chinese population found that polymorphisms in $R A G E$ at $577 \mathrm{G} / \mathrm{A}$ were associated with OA. Their results also indicated that $557 \mathrm{G} / \mathrm{A}$ was positively associated with obesity (Han et al., 2012). However, no interaction was found between obesity and $R A G E$ polymorphisms in the current study (data not shown). In the present study, the $R A G E-374 \mathrm{~T} / \mathrm{A}$ polymorphism showed no association with $\mathrm{OA}$, but the $R A G E-429 \mathrm{~T} / \mathrm{C}$ and $577 \mathrm{G} / \mathrm{A}$ polymorphisms were found to be associated with OA. The $-429 \mathrm{~T} / \mathrm{C}$ and $-374 \mathrm{~T} / \mathrm{A}$ polymorphisms exerted a marked effect on transcriptional activity, and the $577 \mathrm{G} / \mathrm{A}$ (G82S) polymorphism promotes glycosylation of $R A G E$ at asp81 and is associated with enhanced ligand binding and consequent receptor signaling (Li and Schmidt, 1997; Hudson et al., 2001). The RAGE SNPs may affect the susceptibility to OA by altering transcriptional activity.

Thus far, no associations between polymorphisms in the S100A8 gene and OA have been reported. We observed no difference in the frequencies of the $S 100 A 8 \mathrm{rs} 3795391 \mathrm{~A} / \mathrm{G}$ genotype and allele between OA patients and controls. S100A8 rs3795391A/G may have a very small an effect on the susceptibility to OA.

We also identified the haplotypes in $R A G E$ and $M M P-1$, but none were associated with OA. A previous study found a weak association between a $R A G E$ gene promoter haplotype and ischemic stroke in men (Zee et al., 2006), and another study showed that the $M M P-1$ haplotype is associated with OA (Abd-Allah et al., 2012). Our results are inconsistent with these results. Further studies are required to confirm the reported association between the $R A G E$ and $M M P-1$ haplotypes and genetic susceptibility to OA. These findings suggest that a weak association exists between $R A G E$ gene polymorphisms and OA susceptibility.

Our study had some limitations. First, the results apply to the Han Chinese population and may not generalize to other ethnic groups. Our sample size was relatively small, limiting its statistical power to detect existing associations. Second, the complicated process of $R A G E$ gene expression and activity in vivo is unclear, possibly because of modulation by other genes. The continued accumulation in databases of SNP data for other genes will improve such studies.

The investigated polymorphism in the $R A G E$ gene may play a role in $\mathrm{OA}$ in the Han Chinese population. Definitive confirmation of the correlations between $R A G E$ gene polymorphism and OA should be further studied in a larger population size.

\section{Conflicts of interest}

The authors declare that they have no competing interests. 


\section{ACKNOWLEDGMENTS}

Research supported by grants from the National Science Council and Tri-Service General Hospital, Taiwan (\#NSC99-2314-B-016-001, \#TSGH-C100-007-009-10-S03).

\section{REFERENCES}

Abd-Allah SH, Shalaby SM, Pasha HF, El-Shal AS, et al. (2012). Variation of matrix metalloproteinase 1 and 3 haplotypes and their serum levels in patients with rheumatoid arthritis and osteoarthritis. Genet. Test Mol. Biomarkers 16: 15-20.

Barlas IO, Sezgin M, Erdal ME, Sahin G, et al. (2009). Association of $(-1,607) 1 G / 2 G$ polymorphism of matrix metalloproteinase-1 gene with knee osteoarthritis in the Turkish population (knee osteoarthritis and MMPs gene polymorphisms). Rheumatol. Int. 29: 383-388.

Bratus A, Aeschlimann A, Russo G and Sprott H (2013). Candidate gene approach in genetic epidemiological studies of osteoarthritis-related pain. Pain 155: 217-221.

Carroll L, Frazer IH, Turner M, Marwick TH, et al. (2007). Receptor for advanced glycation end products Glycine 82 Serine polymorphism and risk of cardiovascular events in rheumatoid arthritis. Arthritis Res. Ther. 9: R39.

Checa M, Ruiz V, Montano M, Velazquez-Cruz R, et al. (2008). MMP-1 polymorphisms and the risk of idiopathic pulmonary fibrosis. Hum. Genet. 124: 465-472.

Daborg J, von Otter M, Sjolander A, Nilsson S, et al. (2010). Association of the RAGE G82S polymorphism with Alzheimer's disease. J. Neural. Transm. 117: 861-867.

Gonzalez A (2013). Osteoarthritis year 2013 in review: genetics and genomics. Osteoarthritis Cartilage 21: 1443-1451.

Grogan SP and D'Lima DD (2010). Joint aging and chondrocyte cell death. Int. J. Clin. Rheumtol. 5: 199-214.

Han Z, Liu Q, Sun C and Li Y (2012). The interaction between obesity and RAGE polymorphisms on the risk of knee osteoarthritis in Chinese population. Cell Physiol. Biochem. 30: 898-904.

Hofmann MA, Drury S, Fu C, Qu W, et al. (1999). RAGE mediates a novel proinflammatory axis: a central cell surface receptor for S100/calgranulin polypeptides. Cell 97: 889-901.

Hofmann MA, Drury S, Hudson BI, Gleason MR, et al. (2002). RAGE and arthritis: the G82S polymorphism amplifies the inflammatory response. Genes Immun. 3: 123-135.

Hudson BI, Stickland MH, Futers TS and Grant PJ (2001). Effects of novel polymorphisms in the RAGE gene on transcriptional regulation and their association with diabetic retinopathy. Diabetes 50: 1505-1511.

Jin X, Kuang G, Wei LZ, Li Y, et al. (2005). No association of the matrix metalloproteinase 1 promoter polymorphism with susceptibility to esophageal squamous cell carcinoma and gastric cardiac adenocarcinoma in northern China. World J. Gastroenterol. 11: 2385-2389.

Jurajda M, Muzik J, Izakovicova Holla L and Vacha J (2002). A newly identified single nucleotide polymorphism in the promoter of the matrix metalloproteinase-1 gene. Mol. Cell Probes 16: 63-66.

Kalousova M, Brabcova I, Germanova A, Jachymova M, et al. (2009). RAGE polymorphisms, renal function and histological finding at 12 months after renal transplantation. Clin. Biochem. 42: 347-352.

Kerkhof HJ, Lories RJ, Meulenbelt I, Jonsdottir I, et al. (2010). A genome-wide association study identifies an osteoarthritis susceptibility locus on chromosome 7q22. Arthritis Rheum. 62: 499-510.

Kokkola R, Li J, Sundberg E, Aveberger AC, et al. (2003). Successful treatment of collagen-induced arthritis in mice and rats by targeting extracellular high mobility group box chromosomal protein 1 activity. Arthritis Rheum. 48: 2052-2058.

Li J and Schmidt AM (1997). Characterization and functional analysis of the promoter of RAGE, the receptor for advanced glycation end products. J. Biol. Chem. 272: 16498-16506.

Li Q, Meng H, Zhang L, Xu L, et al. (2007). Correlation between single nucleotide polymorphisms in a calprotectin subunit gene and risk of periodontitis in a Chinese population. Ann. Hum. Genet. 71: 312-324.

Loeser RF, Yammani RR, Carlson CS, Chen H, et al. (2005). Articular chondrocytes express the receptor for advanced glycation end products: Potential role in osteoarthritis. Arthritis Rheum. 52: 2376-2385.

Martel-Pelletier J and Pelletier JP (1996). Wanted - the collagenase responsible for the destruction of the collagen network in human cartilage! Br. J. Rheumatol. 35: 818-820.

Pang H, Luo F, Dai F, Wu XH, et al. (2013). Genome-wide association study for osteoarthritis. Lancet 381: 372-373.

Reddy MA, Li SL, Sahar S, Kim YS, et al. (2006). Key role of Src kinase in S100B-induced activation of the receptor for advanced glycation end products in vascular smooth muscle cells. J. Biol. Chem. 281: 13685-13693.

Reynard LN and Loughlin J (2013). The genetics and functional analysis of primary osteoarthritis susceptibility. Expert Rev. Mol. Med. 15: e2. 
Roth J, Goebeler M and Sorg C (2001). S100A8 and S100A9 in inflammatory diseases. Lancet 357: 1041.

Sofat N (2009). Analysing the role of endogenous matrix molecules in the development of osteoarthritis. Int. J. Exp. Pathol. 90: 463-479.

Sokolove J and Lepus CM (2013). Role of inflammation in the pathogenesis of osteoarthritis: latest findings and interpretations. Ther. Adv. Musculoskelet. Dis. 5: 77-94.

Valdes AM and Spector TD (2009). The contribution of genes to osteoarthritis. Med. Clin. North Am. 93: 45-66.

van den Berg WB (2011). Osteoarthritis year 2010 in review: pathomechanisms. Osteoarthritis Cartilage 19: 338-341.

Wicki R, Marenholz I, Mischke D, Schafer BW, et al. (1996). Characterization of the human S100A12 (calgranulin C, p6, CAAF1, CGRP) gene, a new member of the S100 gene cluster on chromosome 1q21. Cell Calcium 20: 459-464.

Ye S (2000). Polymorphism in matrix metalloproteinase gene promoters: implication in regulation of gene expression and susceptibility of various diseases. Matrix Biol. 19: 623-629.

Yuan GH, Masuko-Hongo K, Kato T and Nishioka K (2003). Immunologic intervention in the pathogenesis of osteoarthritis. Arthritis Rheum. 48: 602-611.

Zee RY, Romero JR, Gould JL, Ricupero DA, et al. (2006). Polymorphisms in the advanced glycosylation end productspecific receptor gene and risk of incident myocardial infarction or ischemic stroke. Stroke 37: 1686-1690.

Zeggini E, Panoutsopoulou K, Southam L, Rayner NW, et al. (2012). Identification of new susceptibility loci for osteoarthritis (arcOGEN): a genome-wide association study. Lancet 380: 815-823.

Zhang Y and Jordan JM (2010). Epidemiology of osteoarthritis. Clin. Geriatr. Med. 26: 355-369. 